Abstracta Iranica Abstracta Iranica

Revue bibliographique pour le domaine irano-aryen

Volume 25 | 2004

Comptes rendus des publications de 2002

\title{
"The Iron Age and Persian Periods in Jordan ». Studies in the History and Archaeology of Jordan VII, (2001), pp. 265-274.
}

\section{Astrid Nunn}

\section{(2) OpenEdition}

Journals

Édition électronique

URL : http://journals.openedition.org/abstractairanica/4255

DOI : 10.4000/abstractairanica.4255

ISSN : 1961-960X

Éditeur :

CNRS (UMR 7528 Mondes iraniens et indiens), Éditions de l'IFRI

\section{Édition imprimée}

Date de publication : 15 mai 2004

ISSN : 0240-8910

Référence électronique

Astrid Nunn, « "The Iron Age and Persian Periods in Jordan ». Studies in the History and Archaeology of Jordan VII, (2001), pp. 265-274. », Abstracta Iranica [En ligne], Volume 25 | 2004, document 63, mis en ligne le 15 mars 2006, consulté le 25 septembre 2020. URL : http://journals.openedition.org/ abstractairanica/4255; DOI : https://doi.org/10.4000/abstractairanica.4255

Ce document a été généré automatiquement le 25 septembre 2020.

Tous droits réservés 
« The Iron Age and Persian Periods in Jordan ». Studies in the History and Archaeology of Jordan VII, (2001), pp. 265-274.

\section{Astrid Nunn}

L'A. est bien connu pour ses recherches sur l'époque achéménide en Jordanie. Cet article paru en 2001 s'ajoute à ceux parus en même temps dans d'autres livres (voir Abs. Ir. $24 \mathrm{n}^{\circ}$ 52). Un résumé est toujours le bienvenu. Le début de l'époque du Fer reste controversé et diffère de région à région (Ammon, Moab, Edom). Une page et demie est consacrée à la période qui nous concerne. Car même si la période achéménide a pris sa place dans l'histoire de la Jordanie, les traces n'en sont néanmoins pas nombreuses. Un site, celui de Tell Umeiri, livre une bonne stratigraphie du Fer II à l'achéménide. La céramique attique du $5^{\mathrm{e}} \mathrm{s}$. qui est un indice irréfutable pour la datation de la couche archéologique, montre clairement que la tradition céramique du Fer II persistera jusqu'à l'époque hellénistique. Ceci est une des raisons principales pour lesquelles le matériel achéménide est si difficile à reconnaître en Jordanie. La conclusion de l'A. nous incite à rester prudents quant à l'interprétation du matériel connu et à ne pas encore édifier de théorie générale.

\section{INDEX}

Thèmes : 3.2.2. Pré-Achéménides et Achéménides 
AUTEURS

ASTRID NUNN

Université de Munich 